Research, Society and Development, v. 9, n. 11, e45491110225, 2020

(CC BY 4.0) | ISSN 2525-3409 | DOI: http://dx.doi.org/10.33448/rsd-v9i11.10225

\title{
Fermented rice bran: an alternative ingredient in baking ${ }^{1}$
}

Farelo de arroz fermentado: uma alternativa de insumo na panificação Salvado de arroz fermentado: una alternativa de ingrediente para panificación

Received: 13/11/2020 | Reviewed: 14/11/2020 | Accepted: 18/11/2020 | Published: 21/11/2020

Anelise Christ-Ribeiro

ORCID: https://orcid.org/0000-0002-5470-6207

Federal University of Rio Grande, Brazil

E-mail: anelise.christ@hotmail.com

Janaína Barreto Alves

ORCID: https://orcid.org/0000-0002-4043-0705

Federal University of Rio Grande, Brazil

E-mail: ninajbalves@gmail.com

Leonor Almeida de Souza-Soares

ORCID: https://orcid.org/0000-0002-8688-4761

Federal University of Rio Grande, Brazil

E-mail: leonor.souzasoares@gmail.com

Eliana Badiale-Furlong

ORCID: https://orcid.org/0000-0002-5864-8796

Federal University of Rio Grande, Brazil

E-mail: dqmebf@furg.br

\begin{abstract}
The idea that associated agro-industrial by-products only with the production of animal feed has been gradually being replaced, as the scientific community is interested in these products, as low-cost nutrients for the composition of food and/or culture media in research biotechnological to increase or improve nutrients or characteristics inherent in the raw material. Thus, this work aims to characterize input for baking with claim of natural fortification from the fermentation by Saccharomyces cerevisiae. For this, biomass was characterized in terms of its composition (ashes, fibers, lipids, proteins, and carbohydrates)
\end{abstract}

\footnotetext{
${ }^{1}$ Trabalho apresentado no CBCP 2020 - Congresso on-line Brasileiro de Tecnologia de Cereais e Panificação, selecionado para publicação na forma de artigo completo.
} 
and antioxidant activity of phenolic compounds. The results show an increase in nutrients such as ash, proteins and fibers, in addition the free and bound phenolic compounds present in the biomass showed antioxidant potential. Therefore, fermented rice bran is a potential input to be used in baking.

Keywords: Solid-state fermentation; Saccharomyces cerevisiae; Nutritional source; Coproducts.

\section{Resumo}

A ideia que associava coprodutos ou subprodutos agroindustriais somente à produção de ração animal vem gradativamente sendo substituída, à medida que a comunidade científica se interessa por estes produtos, como nutrientes de baixo custo para a composição de alimentos e/ou de meios de cultivo em pesquisas biotecnológicas para aumentar ou melhorar nutrientes ou características inerentes na matéria prima. Devido a isso, este trabalho tem como objetivo caracterizar insumo para panificação com alegação de fortificação natural a partir da fermentação por Saccharomyces cerevisiae. Para isso, a biomassa foi caracterizada quanto a sua composição (cinzas, fibras, lipídios, proteínas e carboidratos) e atividade antioxidante dos compostos fenólicos. Os resultados mostram o aumento de nutrientes como cinzas, proteínas e fibras, além disso os compostos fenólicos ligados e livres presentes na biomassa mostraram potencial antioxidante. Portanto o farelo de arroz fermentado é um potencial insumo para ser utilizado na panificação.

Palavras-chave: Fermentação em estado sólido; Saccharomyces cerevisiae; Fonte nutricional; Coprodutos.

\section{Resumen}

La idea de que los subproductos agroindustriales asociados únicamente a la producción de alimentos para animales se ha ido sustituyendo paulatinamente, a medida que la comunidad científica se interesa por estos productos, como nutrientes de bajo costo para la composición de alimentos y / o medios de cultivo en investigación biotecnológica para incrementar o mejorar nutrientes o características inherentes a la materia prima. Por ello, este trabajo tiene como objetivo caracterizar los insumos para panificación con pretensión de fortificación natural a partir de la fermentación por Saccharomyces cerevisiae. Para ello, se caracterizó la biomasa en cuanto a su composición (cenizas, fibras, lípidos, proteínas y carbohidratos) y actividad antioxidante de los compuestos fenólicos. Los resultados muestran un incremento en nutrientes como cenizas, proteínas y fibras, además los compuestos fenólicos libres y ligados 
presentes en la biomasa mostraron potencial antioxidante. Por lo tanto, el salvado de arroz fermentado es un insumo potencial para ser utilizado en la repostería.

Palabras clave: Fermentación en estado sólido; Saccharomyces cerevisiae; Fuente nutricional; Coproductos.

\section{Introdução}

Rice bran has stood out commercially in the food production chain, as it has been demonstrated beneficial effects of its use for nutritional and functional purposes. Its incorporation into human diets is still limited by the eating habits of some regions. However, its inclusion in food formulations would be very interesting, especially as an ingredient in formulations for individuals with chronic metabolic problems or due to the biological cycle (Irakli et al., 2015; Poulev et al., 2018). Considering that the bran represents $8 \%$ to $11 \%$ of the total weight of the grain and comes from the external cover just below the husk, being removed from the white or parboiled rice, previously husked, during the polishing process, using it with added value also represents an implement for the sustainability of the rice production chain.

According to IRGA data (2019), the southern zone of Rio Grande do Sul, RS was the second largest area planted in the rice crop, equivalent to 105,254 hectares. According to CONAB (2020), production of 10.56 million tons of rice is expected in Brazil, generating around 1.05 million tons of rice bran in the country and, in RS, 862 thousand tons, whose zone south of RS is responsible for 174 thousand tons. At the national level, this potential is more comprehensive, as Brazil is a major agricultural producer and, consequently, there is an expressive generation of residues or agro-industrial by-products, which can become an environmental problem. Therefore, the use of bran is important as a way of adding value, minimizing environmental impact, being viable due to its availability at the regional level and because it is considered a co-product, with some technological and nutritional restrictions for commercialization, especially if naturally enriched.

However, rice bran has some limitations for its application, such as the activity of hydrolytic and oxidative enzymes, median digestibility, and the availability of functional compounds not always achieved during the human digestive process; however, fermentative processes are promising to minimize these effects more efficiently than chemical or physical processes. In this context, rice bran is demonstrated to be a good substrate for solid-state fermentation to Generally Recognized as Safe (GRAS) microorganisms which, when 
developed, promote an increase in the supply of nutrients and functional compounds in foods formulated with this biomass (Christ-Ribeiro et al., 2017; Aalim et al., 2019).

Among the functional compounds, phenolics have a recognized role in preventing diseases such as cancer, diabetes, heart, neurodegenerative and cardiovascular diseases and aging (Christ-Ribeiro et al., 2016; Mark et al., 2019; Furlong et al., 2020). They are found in different forms depending on their association with the food matrix, such as free and soluble esters or linked conjugated and insoluble forms (Zhang et al., 2020). Therefore, the objective of the work was to evaluate the proximal composition and the antioxidant capacity of free and bound phenolic compounds from rice bran fermented by $S$. cerevisiae aiming at the potential application as input for baking.

\section{Metodologia}

\subsection{Experimental procedure}

This is a quantitative study carried out through experimental laboratory research, generating precise and safe original numerical results. The raw material used will be defatted rice bran. For fermentation with yeast, the method described by Feddern et al. (2007) was used, where the rice bran was subjected to solid-state fermentation with yeast $S$. cerevisiae previously hydrated (3\% pp-1) with distilled water, reaching $30 \%$ humidity. The process was carried out in an oven with air circulation at $30{ }^{\circ} \mathrm{C}$ for $0,2,4$, and $6 \mathrm{~h}$ to check the best condition as a natural fortification of rice bran.

To assess the best fermentation time, the proximal composition was performed, determining moisture, ash, fibers, lipids, proteins and carbohydrates by difference, according to AOAC (2000). The phenolic compounds were extracted according to Christ-Ribeiro et al. (2019) using methanol in the proportion of 1:8 (w/v). The mixture was submitted to orbital agitation, $160 \mathrm{rpm}$, for $2 \mathrm{~h}$. After resting for $15 \mathrm{~min}$, another $10 \mathrm{~mL}$ of solvent was added and agitated for more $1 \mathrm{~h}$. The methanolic extracts were evaporated in a route-evaporator and resuspended with distilled water. The resulting extract was clarified, centrifuged, and filtered. The total content of phenolic compounds was determined by spectrophotometer at $750 \mathrm{~nm}$ with Folin-Ciocalteau reagent and quantified using gallic acid standard curve (2 to $30 \mu \mathrm{g} \mathrm{ml}^{-}$

${ }^{1}$ ). Furthermore, antioxidant activities were evaluated by DPPH and ABTS according to Wu et al. (2018). 


\section{Resultados e Discussão}

The bran was fermented, and at each fermentation time, the proximate composition determinations were performed, as shown in Table 1.

Table 1 - Proximal composition of fermented and unfermented rice bran (UF).

\begin{tabular}{cccccc}
\hline Fermentation time & Ash & Protein & Lipid & Fiber & Carbohydrate \\
\hline UF & $13.8^{\mathrm{c}}$ & $7.4^{\mathrm{d}}$ & $30.7^{\mathrm{a}}$ & $5.4^{\mathrm{b}}$ & $31.2^{\mathrm{a}}$ \\
Oh & $14.2^{\mathrm{b}}$ & $12.6^{\mathrm{c}}$ & $20.3^{\mathrm{c}}$ & $5.2^{\mathrm{b}}$ & $15.4^{\mathrm{b}}$ \\
\hline $\mathrm{h}$ & $14.2^{\mathrm{b}}$ & $12.0^{\mathrm{c}}$ & $20.1^{\mathrm{c}}$ & $5.2^{\mathrm{b}}$ & $15.9^{\mathrm{b}}$ \\
$4 \mathrm{~h}$ & $14.2^{\mathrm{b}}$ & $20.5^{\mathrm{a}}$ & $19.4^{\mathrm{c}}$ & $5.5^{\mathrm{b}}$ & $11.2^{\mathrm{c}}$ \\
$6 \mathrm{~h}$ & $14.5^{\mathrm{a}}$ & $19.5^{\mathrm{a}}$ & $20.7^{\mathrm{c}}$ & $6.3^{\mathrm{a}}$ & $7.7^{\mathrm{d}}$ \\
\hline
\end{tabular}

Values are expressed as averages. Values in lines with the same letter (fermentation time) do not indicate significant differences using the Tukey test $(\mathrm{p}<0.05)$. Source: Authors (2020).

According to Table 1, there was an increase in ash, protein, fiber content, and a decrease in lipids and carbohydrates with the application of S. cerevisiae in brown rice bran during fermentation. In alcoholic fermentation, a complex interaction between acetylation, production, and degradation of amino acids occurs through the metabolic pathway of S. cerevisiae (Benucci et al., 2017). Cellulose is strongly linked to hemicelluloses and lignin, which are present in abundance in rice bran, acting as a barrier to producing other compounds from biomass, which, with hydrolytic stability and structural resistance to cell walls, ends up making it resistant to degradation. To overcome the resistance of lignocellulose, we can use biotechnology to achieve higher yields of compounds more quickly. The growth of the microorganism on a substrate alters its chemical composition due to the action of exocellular enzymes and the production of other metabolites specific to the fermenter (Oliveira et al., 2010). These results are in agreement with Feddern et al. (2007), who obtained an increase in ash and fiber by $13 \%$ and $2 \%$, respectively, and a decrease in carbohydrates by $4.8 \%$ in $6 \mathrm{~h}$. Table 2 shows the content of phenolic compounds extracted from fermented bran. 
Research, Society and Development, v. 9, n. 11, e45491110225, 2020

(CC BY 4.0) | ISSN 2525-3409 | DOI: http://dx.doi.org/10.33448/rsd-v9i11.10225

Table 2 - Free and bound phenolic compounds (mg / g) extracted from fermented and unfermented rice bran (UF).

\begin{tabular}{cccccc}
\hline Antioxidant activity & UF & Oh & $2 \mathrm{~h}$ & $4 \mathrm{~h}$ & $6 \mathrm{~h}$ \\
\hline Free & $37.54^{\mathrm{aA}}$ & $35.54^{\mathrm{bA}}$ & $33.66^{\mathrm{bA}}$ & $34.64^{\mathrm{bA}}$ & $37.18^{\mathrm{aA}}$ \\
Bound & $21.89^{\mathrm{aB}}$ & $19.89^{\mathrm{cB}}$ & $20.47^{\mathrm{cB}}$ & $21.79^{\mathrm{bB}}$ & $22.07^{\mathrm{aB}}$ \\
\hline
\end{tabular}

Values are expressed as averages. Values in lines with the same lowercase letter (fermentation time) and values in columns with the same uppercase letter (types of phenolic compounds) do not indicate significant differences by the Tukey test $(p<0.05)$. Source: Authors $(2020)$.

As shown in Table 2, we can see a significant difference between the fermentation times and the type of phenolic compounds. The free phenolic compounds are more available than the bound ones, which was already expected due to the greater ease of extraction because they do not perform complex bonds with other compounds. This relationship is opposite to the linked phenolic compounds, which are characterized by being covalently linked or esterified to sugars and other low molecular weight components, such as fatty acids (Mira et al., 2008; Zhang et al., 2020). The fermentation time of $6 \mathrm{~h}$ is the one with the greatest supply of phenolic compounds, indicating that yeast can interact in complex bonds, increasing the availability of both compounds. Table 3 shows the antioxidant activity of phenolic compounds extracted from fermented bran. 
(CC BY 4.0) | ISSN 2525-3409 | DOI: http://dx.doi.org/10.33448/rsd-v9i11.10225

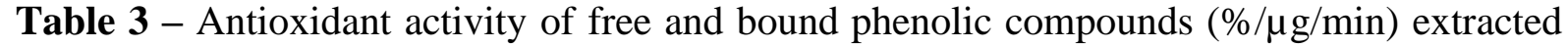
from fermented and unfermented rice bran (UF).

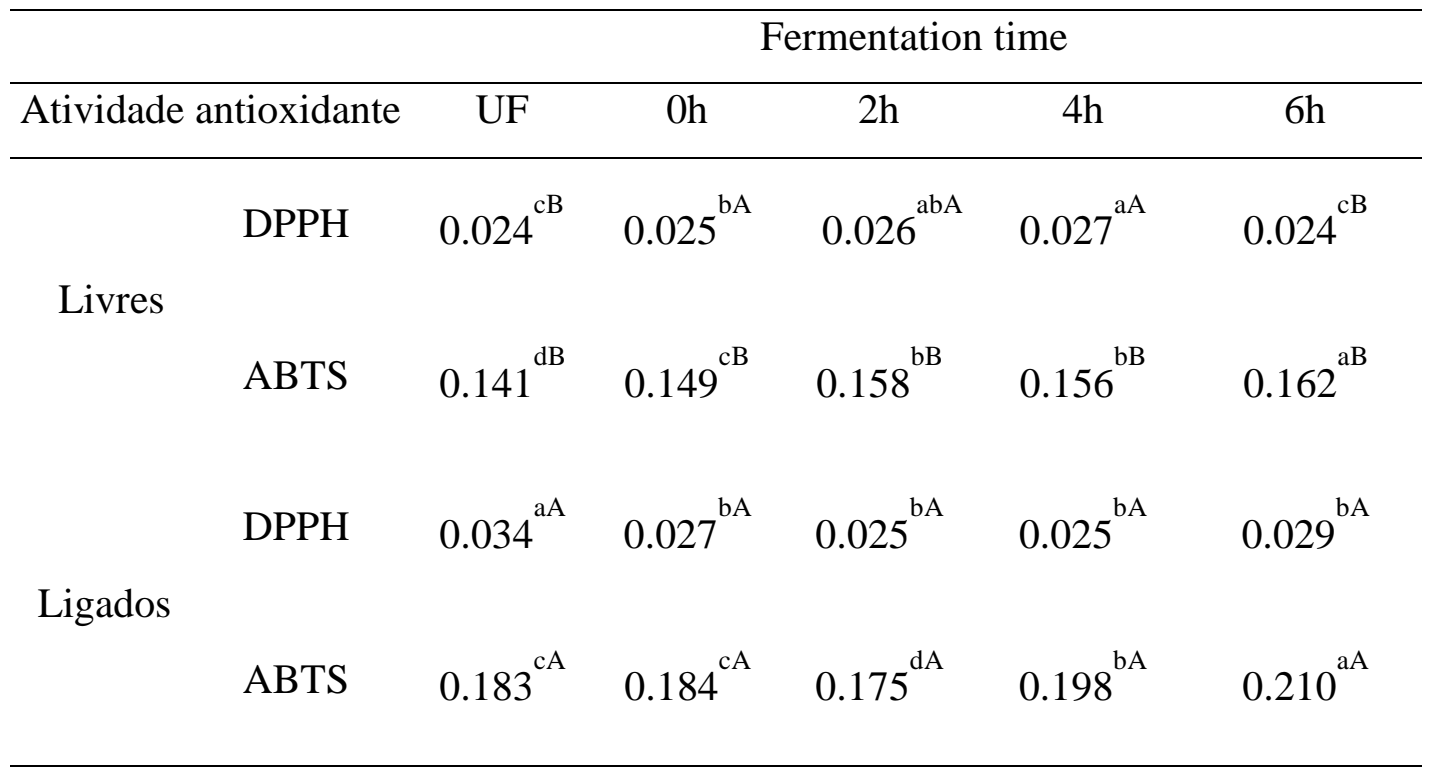

Values are expressed as averages. Values in lines with the same lowercase letter (fermentation time) and values in columns with the same uppercase letter (types of phenolic compounds) do not indicate significant differences by the Tukey test $(\mathrm{p}<0.05)$. Source: Authors $(2020)$.

According to Table 3, it can be seen that the antioxidant activity of the bound phenolic compounds is greater than the free ones. Despite the greater availability of free phenolic compounds in the fermented rice bran, they do not have the greatest antioxidant potential. This function, responsible for the bound phenolic compounds. This can be explained due to the fact that phenolic acids such as hydroxybenzoic and hydroxycinnamic, which act to increase structural rigidity and protect cells with matrix antibacterial, antifungal and antioxidant activities, can form several connections with different groups of the cell wall becoming " trapped "within the matrix by means of hydrogen bonds or hydrophobic interactions (Christ-Ribeiro et al., 2019; Zhang et al., 2020). Thus, with the extraction of the linked phenolic compounds they become available and increase the antioxidant activity as shown in Table 3. In addition, these compounds are important in the connection of cell wall substances, that is, indigestible and fermentable dietary fibers, whose their release and metabolism by the intestinal microbiota can play a key role in unlocking the interactions between the intestinal microbiota, intestinal inflammation, and chronic diseases (Zhang et al., 2020). 


\section{Conclusion}

Biotechnology can add value to an agroindustrial co-product, resulting in improved bioavailability and nutritional enrichment, combined with antioxidant capacity, making biomass a promising alternative as an input in the bakery industry.

Thus, the application as an ingredient in the manufacture of cookies and cakes is promising, mainly for gluten intolerant consumers. Future studies may complement the development of new products, such as breads and cookies, in addition to the claim of functionality of the phenolic compounds present in this input.

\section{References}

Aalim, H., Belwal, T., Jiang, L., Huang, H., \& Luo, Z. (2019). Extraction optimization, antidiabetic and antiglycation potentials of aqueous glycerol extract from rice (Oryza sativa L.) bran. LWT - Food Science and Technology, 103, 147-154.

Association of Official Analytical Chemists (AOAC). Official methods of analysis of AOAC International. 14thed.Washington, 1141, 2000.

Benucci, I., Fiorelli, V., Lombardelli, C., Liburdi, K., \& Esti, M. (2017). Kinetic characterization of arginase from Saccharomyces cerevisiae during alcoholic fermentation at different temperatures. LWT-Food Science and Technology, 821, 268-273.

Christ-Ribeiro, A., Bretanha, C. C., Luz, G. G, Souza, M. M., \& Badiale-Furlong, E. (2016). Compostos fenólicos extraídos de fontes naturais aplicados como conservadores em massas de pizza. Revista de Ciência e Inovação, 1, 129, 2016.

Christ-Ribeiro, A., Graça, C. Da S., Chiattoni, L. M., Massarolo, K. C., Duarte, F. A., Mellado, M. De Las S., \& Soares, L. A. De S. (2017). Fermentation process in the availability of nutrients in rice bran. RR: J MicrobiolBiotechnol, 6(2), 45-52.

Christ-Ribeiro, A., Graça, C. S., Kupski, L., Badiale-Furlong, E., \& Souza-Soares, L. A. de. (2019). Cytotoxicity, antifungal and anti mycotoxins effects of phenolic compounds from fermented rice bran and Spirulina sp. Process Biochemistry, 80, 190-196. 
Companhia Nacional de Abastecimento (CONAB). Acompanhamento da safra brasileira de grãos. 7, SAFRA 2019/20- n.4 - Quarto levantamento, 2020.

Feddern, V., Furlong, E. B., \& Soares, L. A. S. (2007). Efeitos da fermentação nas propriedades físico-químicas e nutricionais do farelo de arroz. Ciência e Tecnologia de Alimentos, 27, 800-804.

Furlong, E. B., Furlong, V. B., Kupski, L., Scaglioni, P. T., Souza, T. D., \& Ribeiro, A. C. (2020). Use of natural resources from Southern Brazil as a strategy to mitigate fungal contamination. Critical Reviews in Food Science and Nutrition, 60, 1-8.

Irakli M., Katsantonis, D., \& Kleisiaris, F. (2015). Evaluation of quality attributes, nutraceutical components and antioxidant potential of wheat bread substituted with rice bran. Journal of Cereal Science. 65, 74-80.

Instituto Rio grandense de Arroz (IRGA). Evolução da Semeadura - Safra 2019/20. https://irga-admin.rs.gov.br/upload/arquivos/201910/31153234-evolucao-semeadura-nates19-20.pdf

Mira, N. V. M., Barros, R. M. C., Schiocchet, M. A., Noldin, J. A., \& Lanfer-Marquez, U. M. (2008). Extração, análise e distribuição dos ácidos fenólicos em genótipos pigmentados e não pigmentados de arroz (Oryza sativa L.). Ciência e Tecnologia de Alimentos, 28(4), 994-1002.

Oliveira, M. Dos S., Feddern, V., KupskI, L., Cipolatti, E. P., Badiale-Furlong, E., \& SouzaSoares, L. A. De (2010). Physico-chemical characterization of fermented rice bran biomass Caracterización fisico-química de la biomasa del salvado de arroz fermentado. Cyta- Journal of Food, 8(3), 229-236.

Poulev, A., Chen, M. H., Cherravuru, S., Raskin, I., \& Belanger, F. C. (2018). Variation in levels of the flavone tricin in bran from rice genotypes varying in pericarp color. Journal of Cereal Science, 79, 226-232. 
Zhang, B., Zhang, Y., LI, H., Deng, Z., \& Tsao, R. (2020). A review on insoluble-bound phenolics in plant-based food matrix and their contribution to human health with future perspectives. Trends in Food Science \& Technology, 105, 347-362.

Wu, N.-N., Li, H.-H., Tan, B., Zhang, M., Xiao, Z.-G., Tian, X.-H., \& Gao, K. (2018). Free and bound phenolic profiles of the bran from different rice varieties and their antioxidant activity and inhibitory effects on a-amylose and a-glucosidase. Journal of Cereal Science, 82, 206-212.

\section{Percentage of contribution of each author in the manuscript}

Anelise Christ-Ribeiro - 30\%

Janaína Barreto Alves - 30\%

Leonor Almeida de Souza-Soares - 20\%

Eliana Badiale-Furlong - 20\% 